\title{
Rulers of the Game: Central Bank Independence During the Interwar Years
}

\section{Citation}

Simmons, Beth A. 1996. Rulers of the game: central bank independence during the interwar years. International Organization 50, no. 3: 407-443.

\section{Published Version}

http://dx.doi.org/10.1017/S0020818300033439

\section{Permanent link}

http://nrs.harvard.edu/urn-3:HUL.InstRepos:3153316

\section{Terms of Use}

This article was downloaded from Harvard University's DASH repository, and is made available under the terms and conditions applicable to Other Posted Material, as set forth at http:// nrs.harvard.edu/urn-3:HUL.InstRepos:dash.current.terms-of-use\#LAA

\section{Share Your Story}

The Harvard community has made this article openly available.

Please share how this access benefits you. Submit a story.

Accessibility 


\title{
Rulers of the game: central bank independence during the interwar years
}

\author{
Beth A. Simmons
}

The recent experience of the European Monetary System has once again brought the problem of international monetary instability to scholars' and policymakers' attention. In 1992, German interest rate hikes meant to address growing inflationary pressures within Germany sparked speculation against the pound and lira that eventually led England and Italy to devalue their currencies and to leave the European Monetary System's Exchange Rate Mechanism (ERM). A year later, the fluctuation bands linking the participating currencies of Europe were widened from 2.5 percent to 15 percent, rendering the system almost as loose as floating exchange rates.

Many observers believe the Bundesbank's decision to raise interest rates to counter domestic inflationary pressures was at the epicenter of the recent European monetary quake. The tremendous independence of the Bundesbank from Bonn has permitted the former to pursue its statutory mandate to preserve the value and stability of the mark virtually free from its own government's interference, and certainly from those of foreigners. From the vantage point of France, where relatively low inflation but an unemployment rate of nearly 12 percent made a tighter monetary policy virtually impossible, the German move meant that "France's closest ally had put its domestic interests before its European responsibilities. It had thereby jeopardized

I have benefited from helpful comments by or discussions with John Aldrich, John Brehm, Barry Eichengreen, Peter Feaver, Robert Franzese Jr., Jeffry Frieden, Peter Gourevitch, Paul Gronke, Keisuke Iida, Atsushi Ishida, Jonathan Kirshner, Peter Lange, David Rowe, and John Zaller. In addition, I benefited from discussions of the evidence and ideas contained herein at Columbia University, Princeton University, University of California, Emory University, and Duke University. The Center for Advanced Study in the Behavioral Sciences (Stanford, California) provided the venue in which much of this article was written, and Georgetown University's Center for German and European Studies provided the venue for extensive revisions. Thanks to Humphrey Costello and Diana Morlang for assistance with SAS programming, to Lyle Scruggs and Tracy Hailey for research assistance, and to David Higdon at the Center for Statistics and Decision Sciences at Duke University for assistance in interpreting probit results. 
progress toward European economic and political union," as summarized by The Economist. ${ }^{1}$

Europeans need not have been surprised that the Bundesbank would place domestic price stability above that of European exchange rates. The central bank faced a familiar internal/external dilemma: the ERM obliged it to defend the weaker currencies in the system either by cutting its own interest rates or by intervening in foreign exchange markets. On the other hand, the Bundesbank had a statutory duty to control German inflation. By virtue of its independence from political interference, the German central bank was able to resist pressure from all directions-from its European allies, German business, and even the German government-to relent with respect to interest rates. ${ }^{2}$ The result, however, was to jettison for the time being the stability of European exchange rates and to dim considerably the prospects for further regional monetary integration.

This episode raises some interesting questions regarding the sources of instability in fixed exchange-rate systems. The central argument of this article is that systemic instability can come from an unlikely quarter: the most independent central banks in the system. And while the current experience of the European Monetary System is suggestive, as is much of the available evidence from the Bretton Woods years, I turn to evidence from an earlier fixed exchange-rate system: the interwar gold exchange standard. In a fashion parallel to some interpretations of recent regional monetary stress in Europe, I argue that central bank independence may have contributed to monetary problems in the 1920s and 1930s due to these banks' singular focus on domestic prices. Such a focus contributed to the deflationary bias of the interwar gold standard - a bias that recently has been identified as a prime reason for the depth and extent of the Great Depression. ${ }^{3}$ The conditions under which deflationary pressures can be a serious problem for international monetary stability are not rare: whenever a major surplus country within a fixed exchange-rate regime during a period of generally slow growth experiences what it perceives to be incipient domestic inflationary pressures, it is likely to take actions that complicate the adjustment process for the rest of the economies in the system. Highly independent central banks are more likely to be domestic inflation hawks, increasing the likelihood of systemic deflation and destabilization under these conditions. ${ }^{4}$

The argument depends on the following observations. First, under fixed exchange rates, it can be difficult for monetary policy simultaneously to achieve the internal goal of domestic price stability and external equilibrium in the balance of payments. Policies that may be desirable from the perspective of domestic price stability (for example, tight monetary policies to keep inflation

1. "In Their Hands?" Economist, 7 August 1993, 21.

2. Davidson-Schmich, 1994.

3. See Eichengreen 1992; and Friedman and Schwartz, 1963.

4. I thank an anonymous reviewer for clarifying this point to me. 
in check) can reinforce an existing surplus on the external account, stimulate gold or capital inflows, and complicate the problem of maintaining fixed exchange rates for other states participating in the system. Second, as is taken for granted in much of the recent political economy literature, central bankers have a tendency to put a high priority on domestic price stability. This may be due to a statutory or constitutional mandate, to their ties to the financial community, or to a process of "socialization" that takes place once they become central bankers. Whatever the source of this priority (an issue not taken up here) domestic price stability is more salient for central bankers than international exchange-rate cooperation when these two values come into conflict. ${ }^{5}$ Third, where central banks are highly independent from government, they are able to pursue their preference for domestic price stability relatively free from political interference, subject to some constraints posed by the possibility of losing their independent status. If these observations are true, then central bank independence-often extolled as a condition conducive to a low rate of inflation-can be responsible for exporting a deflationary bias, and ultimately monetary instability, to the rest of the fixed rate international monetary system.

Scholars have rarely emphasized the potential negative externalities of central bank independence. Rather, the bulk of research attempts to document the felicitous effects of independence on domestic economic outputs. Empirical research for the post-World War II period has uncovered a relationship between central bank independence and lower levels of inflation. ${ }^{6}$ Showing that independence is beneficial to real growth has been more problematic. This topic has been approached by some of the more radical economists critical of the distributive consequences of a "credible" monetary policy." On the apparent assumption that their effects are generally benign, scholars have devoted much recent work to understanding the conditions under which independent central banks are likely to develop. ${ }^{8}$ The recent case of the Bundesbank aside, few have explored the implications of central bank independence for stability and cooperation within a fixed rate regime. ${ }^{9}$

The preferences and priorities of monetary authorities in the major economies are important in understanding what went wrong with the gold exchange standard during the interwar years, just as they have been crucial in understanding the recent disruptions in the European Monetary System. One

5. Woolley, 1984. On the process of socialization of members of the powerful Bundesbank Council, see Marsh 1992.

6. See Bade and Parkin 1982; Banaian, Laney, and Willett 1983; Grilli, Masciandaro, and Tabellini 1991; Alesina and Summers 1993; Fratianni and Huang 1992; and Cukierman, Webb, and Neyapti 1992. For an example of this idea in the conservative financial press, see The Economist, 10 February 1990, 81-82.

7. See Epstein 1991.

8. See Maxfield 1994; Clark 1994; and Bernhard 1994.

9. For arguments that the German Bundesbank took an active role in the collapse of the European Monetary System, see Hefeker 1994. 
important reason why the gold standard was abandoned was that it seemed to require too much price deflation under already recessionary conditions. On top of this, the more independent banks in the system refused to ease interest rates and allow the money supply to expand when they experienced inflows of gold or foreign exchange. To avert the risk of inflation, the more independent central banks maintained their discount rates and sterilized these inflows, rather than accommodating them with a looser monetary policy. The result was a policy that was tighter than the gold exchange standard required-one that contributed to deflation, even as the depression spread from country to country.

I develop this argument by examining the way that fifteen central banks manipulated their discount rates and money supply between 1925 and 1938 . The first section below briefly discusses the adjustment mechanism of the gold exchange standard and then presents two prevailing approaches for understanding international monetary cooperation during the interwar years. The second section describes the two dependent variables to be tested and presents some preliminary descriptive statistics. The third section presents a framework that explains cooperation as a function of central banks' desire to constrain governments' reflationary policies and suggests some hypotheses to be tested. The fourth section describes the methodology I employed and presents the results. Finally, I reflect on the relevance of these findings for contemporary international monetary affairs.

\section{Understanding international monetary cooperation during the interwar years}

Before demonstrating these claims, let us first shed some light on the gold exchange standard and international monetary cooperation during the interwar years. By virtually every account, such cooperation was fragile in this period. Wartime inflation, debt, and destruction of productive facilities made it difficult to stabilize currencies until the mid-1920s. Depression then took its toll on currency stability, as country after country found it necessary to depreciate their currencies to help relieve deflationary pressures. Moreover, there was little concerted macroeconomic cooperation among the major central banks and an apparent unwillingness unilaterally to conduct monetary policy according to the "rules of the game." 10

Since most of the major American and European countries were on a gold exchange standard for at least a portion of the interwar period, it is important to ask what these rules entailed. The gold exchange standard was basically one in which a central bank's gold reserves, which were to be freely convertible into currency at a pegged rate, were augmented by foreign exchange reserves. Like any other international monetary regime, the gold exchange standard was

10. See Clarke 1967; Nurkse 1944; and Dam 1982. 
based on certain expectations about how countries would maintain rough external balance. Writing during one of the deepest years of the depression, the Macmillan Committee on Finance and Industry stated explicitly what most observers and policymakers at the time would have agreed were the primary adjustment norms of the interwar gold standard: "[C]ountries which are losing gold must be prepared to act on a policy which will have the effect of lowering prices, and countries which are receiving gold must be prepared to act on a policy which will have the effect of raising prices."11

The most obvious way in which countries were supposed to act on their domestic price levels in the interest of achieving balance-of-payments equilibrium was through financial orthodoxy (balanced or surplus budgets). ${ }^{12}$ (Surplus fiscal stimulation for purposes of external balance was never seriously considered during the interwar years.) Bloated wartime budgets and outlays for reconstruction were fingered at the international financial conferences held at Brussels in 1920 and Genoa in 1922 as major impediments to international monetary stability. Central banks, of course, typically had little power to influence fiscal budgets directly, but they did wield two other policy instruments that could be used to undermine the inflationary impact of public profligacy. They could both influence interest rates through use of the bank rate and manipulate the money supply through open market operations. The first of these strategies required the central bank of a surplus country to lower its discount rate, which would stimulate the economy and discourage further gold inflows; deficit countries were to raise rates, which would damp down the economy and encourage gold inflows. The second strategy required monetary authorities to adjust the money supply in response to gold inflows or outflows. The central bank of a deficit country experiencing a gold outflow was to contract its money supply, while that of a surplus country was to increase its fiduciary note issue whenever it experienced a gold inflow. ${ }^{13}$ These two mechanisms are the two most important means by which both deficit and surplus countries were expected to make continuous adjustments to both correct incipient international economic imbalances and keep their currencies pegged to gold.

Note that these were effects that were expected to result in the relatively short run. They concentrate on the immediate effects on the capital account (drawing in capital) and current account (reducing domestic demand) but do not explicitly consider the potential long-run effects of high and increasing interest rates (which could affect investment and thus exports over time).

Why did these rules not lead to smoother international adjustments and more stable international monetary relations? International political economy theorists have tended to take a systemic view of the stability of international

11. U.K. Parliament 1931, para. 42.

12. U.K. Parliament 1918, para. 6-7.

13. Willis 1936, 236. 
monetary regimes. Drawing from arguments made by Charles Kindleberger, one approach views international monetary stability as an international public good that can be provided only by a leading nation with the will and ability to police a relatively stable system of exchange rates and encourage the coordination of macroeconomic policies. ${ }^{14}$ Presumably, a dominant economic power should not only conduct its monetary policy as described above, it should also assist or encourage other central banks to do so as well-by, for example, providing temporary liquidity (foreign exchange loans) to avert a currency crisis while the fundamental changes in monetary policy in a deficit country are put into place. It is not clear what kind of leverage the hegemonic power might wield over surplus (gold importing) countries, however.

Kindleberger's view formed the basis of a theory of hegemonic stability that associates a stable international monetary regime with the existence and leadership of a preponderant economic power. This theory has been subject to extensive logical criticism, which has focused primarily on the conditions under which international public goods are likely to be supplied. ${ }^{15}$ It also has been assessed empirically-though primarily for the Bretton Woods monetary system - and found wanting. ${ }^{16}$ In the context of the interwar monetary system, the theory describes what the hegemon ought to have done; it has not adequately explained why the United States did not accept the leadership role during this period.

A second approach has been to argue that the interwar gold standard itself was inherently unstable. One line of argument parallels the famous paradox noted by Robert Triffin in his discussion of the Bretton Woods system: as the world economy grows, international transactions increasingly require reserve currency liquidity; but in a fixed rate regime, as liquidity expands, the system is increasingly vulnerable to a crisis of confidence in the reserve currency itself. ${ }^{17}$ Note that one important feature of the gold exchange system was that a significant part of central bank reserves were in the form of the major foreign currencies (within Europe, primarily the pound). ${ }^{18}$ In this view, the pound's devaluation in 1931 is an outcome parallel to that of the dollar forty years later, and both were the result of an inherent tension between the requirements of liquidity and the requirements of confidence.

Another view, championed by John Maynard Keynes in the late 1930s, is that the gold exchange standard was fatally flawed because it allowed for an asymmetrical evasion of adjustment responsibilities between surplus and deficit countries. While deficit countries ultimately were constrained by reserve losses, surplus countries faced no such constraints. The latter could simply allow their foreign reserves to increase, without making any upward adjust-

14. Kindleberger 1986.

15. Snidal 1985.

16. See Odell 1982; Gowa 1983; Keohane 1984; and Walter 1991.

17. Triffin 1960. See also Oye 1992 .

18. For a contemporaneous account of this inherent problem of the gold exchange standard, see Mlynarski 1929 
ments in their domestic money supply or price levels. Keynes made this point explicitly in his call for an International Clearing Union in September 1941:

To begin with, the social strain of an adjustment downwards is much greater than that of an adjustment upwards. And besides this, the process of adjustment is compulsory for the debtor and voluntary for the creditor. If the creditor does not choose to make, or allow, his share of the adjustment, he suffers no inconvenience. For whilst a country's reserve cannot fall below zero, there is no ceiling which sets an upper limit. The same is true if international loans are to be the means of adjustment. The debtor must borrow; the creditor is under no such compulsion. ${ }^{19}$

Debtor countries had to deflate in order to maintain fixed parities, while surplus countries could resist stimulation. This refusal of surplus countries to adjust was cited by Keynes, and more recently by economic historians, as an important reason for the dysfunctional (that is, deflationary) nature of the interwar gold standard. ${ }^{20}$

It is for these reasons that Keynes and others argued that policies that responded exclusively to domestic considerations (the luxury of surplus countries) were likely on average to produce worse outcomes than policies that followed rules reflecting a more symmetrical distribution of adjustment responsibilities. Such rules were more likely to produce stable exchange rates and minimize systemic biases in price movements due to monetary policies and to split the burden of adjustments among regime adherents. These were the international public goods to be expected from adherence to the rules. The national (private) cost was the loss of a degree of domestic monetary policy autonomy - a price, arguably, that the larger more insular states in the system were reluctant to pay.

Yet structural variables alone are hardly the most crucial in understanding the willingness to play by these rules. Some of the most important explanations are institutional and political. The evidence presented below will suggest that, under certain conditions, inflation-conscious central banks refused to allow expansionary adjustment to take place even though they were in surplus. When faced with the tension between the perceived requirements of domestic price stability and the demands of external adjustment, the more independent central banks, as well as those banks serving under left-leaning governments, opted for domestic price stability-despite potential deflationary consequences for the exchange rate system.

\section{Dependent variables}

To show that independent central banks chose policies that tended to export deflation requires plausible measures of continuous symmetrical policies that

19. Keynes 1980,28 , emphasis original.

20. See Kindleberger 1986; and Eichengreen 1992. 
can be compared with those required for external adjustment. Cooperative bank rate policy and money supply policy comprise two such measures. One can think of these two tools as distinct ways to influence relative prices and hence the balance of payments. A quantitative theory of money-an approach most closely resembling economic thinking during the interwar years-would stress the crucial importance of the money supply in influencing price levels but would expect interest rates to move in a manner consistent with the money supply. A Keynesian approach would place more emphasis on the interest rate itself in influencing aggregate demand but would recognize that it could be influenced by both open market operations and the bank rate.

\section{Cooperative bank rate policy}

Altering the bank rate-the rate charged financial institutions to borrow from the central bank-was the traditional way to influence capital and gold flows and hence to alter the balance of payments and defend the value of a country's currency. ${ }^{21}$ To refer to the Cunliffe Committee report once again, balance-of-payments deficits could be traced to government borrowing, which in turn was linked to slack credit policies, such that the "growth of purchasing power [had] exceeded that of purchasable goods and services.... When the exchanges are adverse and gold is being drawn away it is essential that the rate of discount in this country [the United Kingdom] should be raised relatively to the rates ruling in other countries." 22

If central banks were using their bank rate to counter changes in their external accounts, one would expect to observe a negative relationship between changes in the foreign reserves of the central bank (an indicator of pressure on the balance of payments) and the bank rate in the following period. One can then distinguish cooperative from noncooperative adjustment policy by coding as "cooperative" all cases in which the change in the bank rate and the change in foreign assets of the central bank move in opposite directions. The remaining noncooperative cases (where these changes move in the same direction) can further be classified as "overly expansionary" if gold outflows were followed by a reduction in bank rate and "overly deflationary" where inflows were followed by bank rate increases, in a scheme shown in Table 1 . This scheme classifies 41.5 percent of observations (eighty-one cases) for fifteen countries as cooperative. (The unit of analysis is a "country-year.") Fifty-eight cases (29.7 percent) were defined as deflationary and fifty-six $(28.7 \%)$, as inflationary.

There were important differences in the apparent willingness of central banks to use the bank rate to counter gold and capital inflows over this period, however. Figure 1 plots the average rate policy as well as the variance in bank

21. For a model of political economic correlates of capital flows and changes in the current account, see Simmons 1994.

22. U.K. Parliament 1918, as reprinted in Eichengreen 1985, 177. 
TABLE 1. Coding of central bank adjustment policy

Conditions

Gold inflows, and lower bank rate $t_{t+1}$

Gold inflows, and higher bank rate $t_{t+1}$

Gold outflows $s_{t}$ and lower bank rate $e_{t+1}$

Gold outflows and higher bank rate $e_{t+1}$
Classification

Code

Cooperative

Deflationary

Inflationary

Cooperative

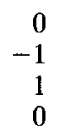

rate policy for fifteen countries between 1925 and 1938 . The ideal policy would be near zero, on average, with a low variance. Unsurprisingly, Poland, Germany, Italy, Hungary, and Japan all had overly inflationary bank rate policies on average during this period, while the United Kingdom, Sweden, and the United States tended to be overly deflationary. Denmark, Austria, and Norway had averages near zero, but their bank rate policies, when considered as an external adjustment mechanism, were highly variable.

\section{Cooperative money supply policy}

Evidence of a central bank's effort to manipulate money supply through open market operations may be found directly in its balance sheets, where changes in domestic assets (e.g., domestic bonds) and changes in foreign assets (foreign exchange and gold flows) are recorded. If central banks are adjusting their money supply to counter gold flows, domestic and foreign assets of the central bank should move in the same direction. In the case of gold inflows (an increase

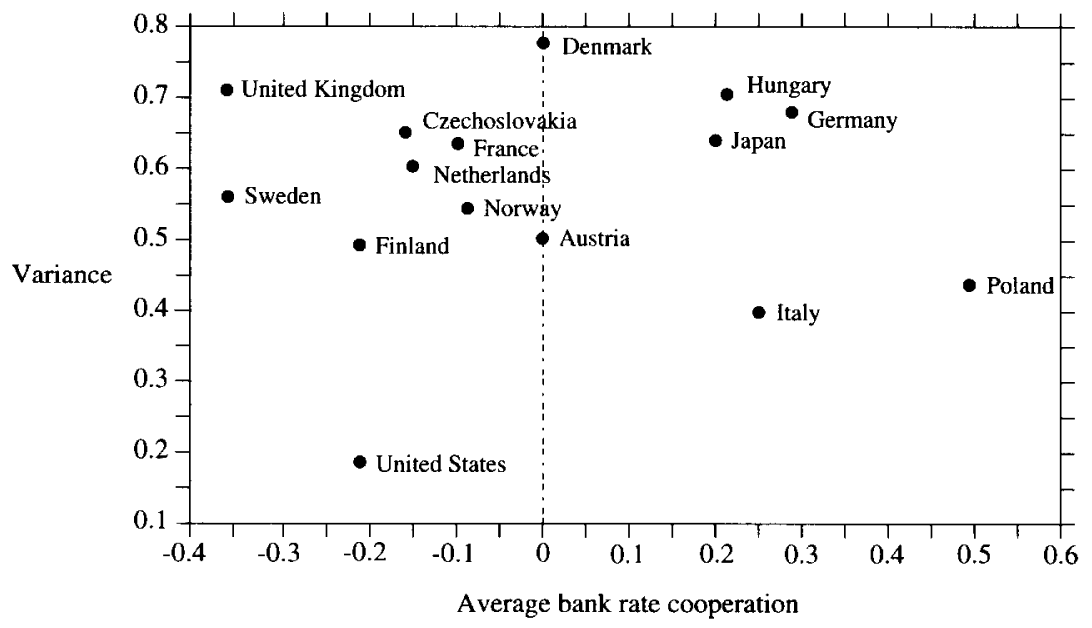

FIGURE 1. Cooperative bank rate adjustment policy for fifteen countries, 1925-38, where points nearest the origin represent the cooperative ideal 
in foreign assets) the central bank should expand the money supply by buying domestic bonds, thus increasing its domestic bond portfolio (an increase in domestic assets) - the so-called rules of the game. It is true that a certain degree of automatic adjustment takes place because an increase in a country's external reserves also entails an increase in the reserves of the commercial banking system, while a decrease in external reserves would entail a decrease in the reserves of the commercial banking system. But if commercial banks try to keep a fairly constant supply of credit available to their customers, then a certain degree of "neutralization" will result. The criterion I used requires the central bank to overcome any such neutralization and reinforce the automatic movement in bank reserves with deliberate expansions or contractions of the money supply. ${ }^{23}$

Ragnar Nurkse looked at the patterns in foreign and domestic central bank assets for this period and concluded that very little cooperation actually took place. ${ }^{24} \mathrm{He}$ labeled an outcome "cooperative" if foreign and domestic assets moved in the same direction in any given year. Nurkse noted that the directions of movement were different about 60 percent of the time and were the same about 32 percent of the time (for approximately the same set of countries considered below). He concluded that the rules of the gold exchange standard were violated frequently during these years and partly attributed the instability of the interwar monetary system to these violations. Nurkse's work continues to be frequently cited as providing evidence that central banks engaged in very little cooperative adjustment during the interwar years. ${ }^{25}$

His analysis has three serious shortcomings, however. First, it would seem appropriate to consider change in domestic money supply using a one-year lag. Even by Nurkse's criterion, signs of foreign and domestic asset movement were in the same direction, indicating cooperative policy, more than half the time when the central bank is allowed one year to adjust the money supply. Second, by considering only the direction of change, Nurkse dichotomized the data and thereby lost a significant amount of information (that is, he did not distinguish an inflationary case from a deflationary one, or a minor inflationary response from a strong one). Third, he made no effort to explain the pattern of rule adherence and rule abrogation he observed. In short, Nurkse's analysis—one of the most highly regarded sources of data on interwar gold standard rule violation-has produced an oversimplified and exaggerated picture, without explaining the patterns that emerge.

To obtain a better sense of the extent to which the adjustment rules of the gold exchange standard were violated, I transform the asset data on the basis of the following assumption: a one-year time lag between changes in foreign assets and adjustments in domestic assets; and a fractional banking system in

23. For a defense of this more active or strict definition of cooperation, see Bloomfield $1959,47$.

24. Nurkse 1944.

25. See Bloomfield 1959, 48; Eichengreen 1992; Dam 1982; and Yeager 1976. 




FIGU RE 2. Distribution of money adjustments for twenty countries, 1925-38, in country-years, where zero is the cooperative ideal

which one unit of reserves in the banking system generates three units of domestic liquidity. This ratio of one to three was the purported practice of many of the major central banks at the time. ${ }^{26} \mathrm{~A}$ perfectly cooperative monetary policy is given by the equation: percentage change in domestic assets at time $t \times 0.3=$ percentage change in foreign assets at time $t-1$. Or, by taking the difference, we can see how much adjustment policy deviated from zero, with the more deflationary cases given by negative numbers and the more inflationary choices given by positive numbers: monetary adjustment $=$ percentage change in domestic assets at time $t \times 0.3-$ percentage change in foreign assets at time $t-1$. Using this measure, we can explore whether and why some countries were overly inflationary (they did not contract their money supply sufficiently) while others were overly deflationary (they sterilized gold inflows by refusing to expand their money supply).

Figure 2 indicates how the money supplies of fifteen countries were distributed around the cooperative ideal during the interwar years. (Nine estimated data points were excluded from the figure.) The data are distributed fairly normally around zero, which implies that in most cases, central banks were in fact playing by this adjustment rule. Values in the negative region indicate policies that are more deffationary than desirable; those in the positive region were more inflationary than desirable by this standard.

Figure 3 comprises a scatter plot of each country's mean and variance with respect to its money supply policy, as defined above. As the figures show, with respect to money supply policy, more countries tended to cluster in the negative

26. For an analysis that estimates this ratio rather than stipulating it, see Eichengreen 1989. 


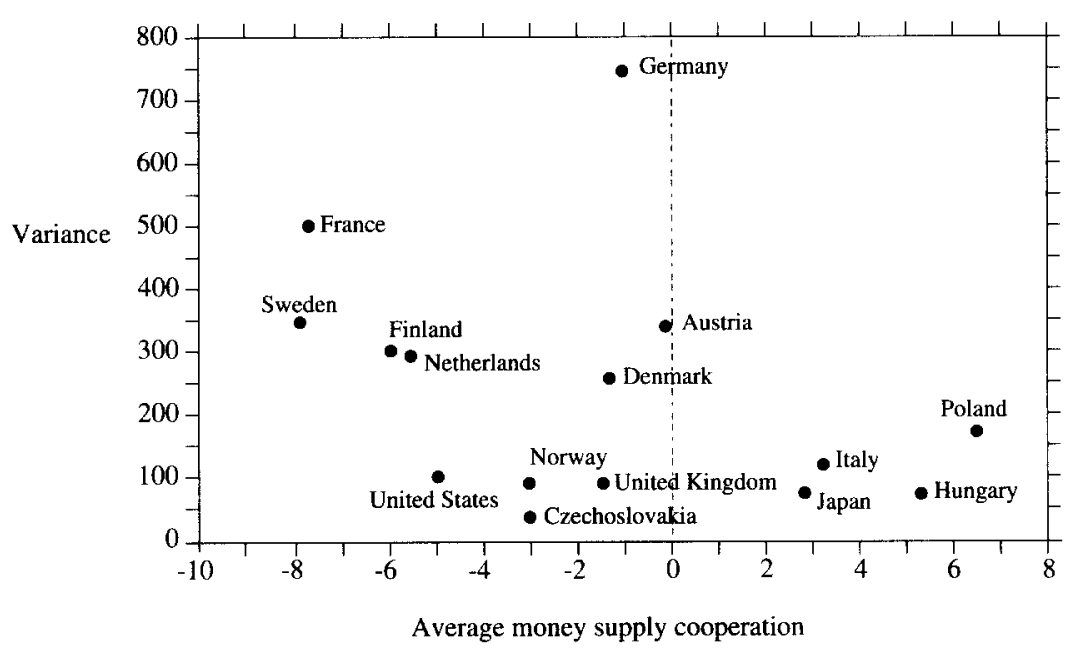

FIG URE 3. Average and variance: cooperative money supply adjustment for fifteen countries, 1925-38, where points nearest the origin represent the cooperative ideal

(deflationary) region than in the positive (inflationary) region. As above, high variance indicates wide swings in money supply policies; low variance indicates countries that truly were on the mark most of the time. The closer to the origin (along both dimensions), the closer a country's policies were to the gold exchange standard ideal. Reassuringly, the scatter diagram shows that two countries that case study analyses generally have portrayed as gold sterilizers (France and the United States) do indeed fall where we would expect them to be: in the deflationary portion of the diagram.

One striking feature of these measures of bank rate and money supply policies is that country averages are highly correlated (correlation $=0.87$; d.f. $=14 ; R^{2}=0.753 ; p<0.0001$ ), though country variances were much less so (correlation $=0.385 ; R^{2}=0.149 ; P<0.156$ ). By both measures, Poland had the most inflationary central bank policies in the sample; those of Sweden, the United States, Netherlands, and France were among the more deflationary. Switzerland (which is excluded from these figures but had a mean of -12.85 and a variance of 1,080 for its money supply policy) was clearly the most apt to resist monetary inflation despite gold inflows and had a highly sporadic policy as well. The United Kingdom's policy was closest to the money supply adjustment ideal, but its policies were highly deflationary and inconsistent with respect to bank rate for the period as a whole.

Bank rate, money supply, and domestic business cycles

The most obvious hypothesis regarding monetary policy during the interwar years is that policy reacted to the domestic business cycle rather than to 
incipient external imbalance. ${ }^{27}$ The "domestic" hypothesis holds that as the economy begins to heat up, central banks tend to implement monetary policies that are deflationary; similarly, under recessionary conditions central banks use the bank rate and money supply to stimulate domestic growth. If this is the case, then for each country examined we should see a strong positive relationship between some macroeconomic indicator, such as growth, and the bank rate in the next period. (Here I employed average bank rate per period for each country year.) We should also observe a strong negative relationship between the business cycle measure in the current period and bank rate and money supply manipulation in the following period. Tables 2 and 3 indicate that the expected domestic economic correlation held for many countries over this period, but did so convincingly only for the money supply. However, the direction and strength of this relationship varied by country. For seven countries, the correlations between the business cycle and money supply manipulation in the following year were in the expected direction and were statistically significant. This relationship was strongest for Austria, Germany, and Czechoslovakia. Czechoslovakia fits the domestic hypothesis on both counts-its central bank apparently tended to use both of these tools to pursue domestic economic stability. The U.S. Federal Reserve also tended to conduct its policy so as to counter growth in the previous period, though one can say little about its use of bank rate. France and Netherlands, both members of the gold bloc until it collapsed in 1936, show the strongest tendency to pursue pro-cyclical money supply policies: they deflated most when growth already was declining and tended to inflate during an upswing. Oddly, in France's case, this unexpected pro-cyclical tendency may even have been reinforced somewhat with the bank rate. ${ }^{28}$

What do these descriptive statistics and country-by-country simple correlations suggest? Primarily, that countries varied noticeably in their willingness to respond to changes in the balance of payments with the traditional adjustment remedies and that there is ample room for domestically motivated monetary

27. Business cycles are taken here as exogenous, although they almost certainly are related to some measures of domestic monetary policy in the previous period (though not directly to the dependent variables proposed here). For example in the simple regression

$\% \Delta I I P=a+\beta\left(\% \Delta\right.$ banks notes $\left._{t-1}\right)+e$,

where the dependent variable is change in the index of industrial production, $a$ is a constant term, $e$ is an error term, and the explanatory variable is rate of growth of bank notes in circulation-a crude measure of the money supply often used during this period. $\beta$ is estimated to be 0.292 with $p<$ 0.001 and adjusted $R^{2}$ of 0.301 . However, the dependent variables tested here are not themselves correlated with $\% \Delta I I P$ (correlation -0.064 and -0.075 for the ratio of bank assets and change in bank rate, respectively), which raises our confidence that the specification does not involve serious simultaneity bias. The fact that monetary policy could be and was used to influence the domestic business cycle in the next period helps to motivate the expected relationship explored here, namely, that between the business cycle and policies that were more likely aimed at domestic conditions rather than external adjustment.

28. For detailed case studies that explore France's inflationary tendencies in the $1920 \mathrm{~s}$ and deflationary tendencies during the first half of the 1930s, see Simmons 1994, chaps. 5 and 7. 
TABLE 2. Simple correlation between the index of industrial production and changes in bank rates of fifteen central banks 1925-1938 (arranged by strength and direction of correlation) ${ }^{\mathrm{a}}$

\begin{tabular}{|c|c|c|c|}
\hline Country & $\begin{array}{c}\text { Coefficient } \\
\text { (Standard error) }\end{array}$ & Correlation & $\begin{array}{l}\text { Degrees of } \\
\text { freedom }\end{array}$ \\
\hline Denmark & $\begin{array}{c}0.035 \\
(0.025)\end{array}$ & 0.392 & 12 \\
\hline Czechoslovakia & $\begin{array}{c}0.018 \\
(0.035)\end{array}$ & 0.39 & 12 \\
\hline Sweden & $\begin{array}{c}0.03 \\
(0.022)\end{array}$ & 0.376 & 12 \\
\hline Poland & $\begin{array}{c}0.028 \\
(0.020)\end{array}$ & 0.33 & 12 \\
\hline Italy & $\begin{array}{c}0.033 \\
(0.032)\end{array}$ & 0.299 & 12 \\
\hline Germany & $\begin{array}{c}0.015 \\
(0.024)\end{array}$ & 0.183 & 12 \\
\hline Netherlands & $\begin{array}{c}0.012 \\
(0.036)\end{array}$ & 0.104 & 12 \\
\hline Japan & $\begin{array}{c}0.006 \\
(0.024)\end{array}$ & 0.078 & 12 \\
\hline United Kingdom & $\begin{array}{c}-0.001 \\
(0.016)\end{array}$ & -0.005 & 12 \\
\hline Austria & $\begin{array}{c}-0.021 \\
(0.162)\end{array}$ & -0.076 & 5 \\
\hline Norway & $\begin{array}{c}-0.006 \\
(0.014)\end{array}$ & -0.128 & 12 \\
\hline United States & $\begin{array}{c}-0.008 \\
(0.016)\end{array}$ & -0.142 & 12 \\
\hline Hungary & $\begin{array}{c}-0.033 \\
(0.047)\end{array}$ & -0.211 & 12 \\
\hline France & $\begin{array}{c}-0.016 \\
(0.022)\end{array}$ & -0.213 & 12 \\
\hline Finland & $\begin{array}{c}-0.023 \\
(0.014)\end{array}$ & -0.436 & 12 \\
\hline All observations & $\begin{array}{c}0.003 \\
(0.006)\end{array}$ & 0.039 & 186 \\
\hline
\end{tabular}

${ }^{\mathrm{a}}$ Bank rate $=$ actual change in bank rate from the previous period. 
TABLE 3. Simple correlation between the index of industrial production and changes in money supply adjustment for fifteen countries, 1925-38 (arranged by strength and direction of correlation)

\begin{tabular}{|c|c|c|c|}
\hline Country & $\begin{array}{c}\text { Coefficient } \\
\text { (Standard error) }\end{array}$ & Correlation & $\begin{array}{l}\text { Degrees of } \\
\text { freedom }\end{array}$ \\
\hline Austria & $\begin{array}{l}-95.302^{* * *} \\
(24.266)\end{array}$ & -0.764 & 12 \\
\hline Germany & $\begin{array}{c}-105.246^{* * *} \\
(32.462)\end{array}$ & -0.683 & 13 \\
\hline Czechoslovakia & $\begin{array}{c}-23.10^{* * *} \\
(8.97)\end{array}$ & -0.597 & 13 \\
\hline Finland & $\begin{array}{l}-71.514^{* *} \\
(28.222)\end{array}$ & -0.59 & 13 \\
\hline Japan & $\begin{array}{l}-68.744^{* *} \\
(29.77)\end{array}$ & -0.555 & 13 \\
\hline Sweden & $\begin{array}{c}-97.037^{*} \\
(50.248)\end{array}$ & -0.487 & 13 \\
\hline United States & $\begin{array}{r}-31.935^{*} \\
(17.744)\end{array}$ & -0.461 & 13 \\
\hline Norway & $\begin{array}{c}-22.294 \\
(17.188)\end{array}$ & -0.355 & 13 \\
\hline Hungary & $\begin{array}{c}-40.122 \\
(35.345)\end{array}$ & -0.338 & 11 \\
\hline Poland & $\begin{array}{c}-26.329 \\
(29.378)\end{array}$ & -0.261 & 12 \\
\hline Denmark & $\begin{array}{c}-25.142 \\
(47.783)\end{array}$ & -0.15 & 13 \\
\hline United Kingdom & $\begin{array}{c}-12.984 \\
(30.361)\end{array}$ & -0.123 & 13 \\
\hline Italy & $\begin{array}{l}-5.004 \\
(48.958)\end{array}$ & -0.034 & 10 \\
\hline France & $\begin{array}{c}21.506 \\
(69.965)\end{array}$ & 0.10 & 10 \\
\hline Netherlands & $\begin{array}{c}41.247 \\
(46.788)\end{array}$ & 0.247 & 13 \\
\hline All observations: & $\begin{array}{c}-45.592^{* * *} \\
(8.69)\end{array}$ & -0.349 & 199 \\
\hline
\end{tabular}

${ }^{*} p<0.10$
${ }^{* *} p<0.05$
${ }^{* *} p<0.01$ 
TABLE 4. Cases in which deflationary externalization was likely to be tempting, 1925-38

Year

$\begin{array}{cc}1920 s & 1930 s \\ \text { Country } & \text { (Systemic growth) }\end{array}$

Austria
Denmark
Finland
France
Germany
Hungary
Japan
Netherlands
Norway
Poland
Sweden
United Kingdom
United States

1926
1925
$1927^{b}$
1926,1928
-
$\overline{-}$
1929
1926
-
-

-
-
1936,1938
-
-
1938
1937
-
1936,1937
-
$1935,1936,1937$
1936
$1934,1935,1936,1938$

aCase criteria are: a 5 percent increase in the index of industrial production ("incipient inflationary pressures") followed by a 10 percent increase in foreign exchange reserves (surplus on external account) in the following period.

bItalics indicate cases that could have serious implications for systemwide monetary stability and deflation.

policy to interfere with the gold exchange external adjustment mechanism. For example, when a surplus country experiences a spurt in domestic economic activity and the central bank expects price inflation to follow, it will likely give heavy priority to moderating prices, and the monetary expansion necessary for external adjustment will be unlikely to take place. The result will be higher interest rates and gold sterilization (that is, the refusal to expand the money supply in response to increases in foreign reserves) and a concomitant deflation-inducing reduction in the liquidity available systemwide to finance economic activity.

While central banks may choose to sterilize reserves or raise the bank rate for any number of reasons, it is most tempted to do so to counter domestic business cycles. But just how often might one expect this to pose a problem for external adjustment? Table 4 lists those cases in which the tension between allaying fears of domestic inflation and external adjustment were most likely to come into conflict during this period (that is, when the temptation to externalize deflation was greatest). It shows years and countries in which a 5 percent increase in the index of industrial production was followed by evidence of an improving external position (a 10 percent or greater increase in foreign reserves of the central bank). The 1920s are separated from the 1930s, since the 
systemic impact of such domestically motivated deflation is much likely to be greater in a general downturn. Yet both France and the Netherlands faced conditions in the $1920 \mathrm{~s}$ in which it made sense, from a national perspective, to tighten their monetary policy, with serious implications for the pound sterling and hence the international monetary system as a whole. Even more stark is the tension faced by Japan, Sweden, the United Kingdom, and-most seriously for the international economy - the United States in the mid-1930s. As industrial production began to rebound, their external positions continued to improve, raising the temptation to sterilize gold and reserves without expanding the monetary base or lowering interest rates. Yet the 1930s were hardly the time, by most accounts, for monetary tightening. According to Barry Eichengreen's recent study of the interwar monetary system, the practice of gold sterilization "was the main source of stress on the international monetary system." ${ }^{29}$ I now present evidence of the political and institutional conditions under which the externalization of deflation in fact tended to take place.

\section{Central bank policies}

\section{A conceptual framework for analysis}

National central banks varied considerably in their willingness to play by the rules of the game during the interwar period. What explains this variation?

I begin by positing some basic preferences of central bankers and governments that have a strong basis in theory and that are often revealed in fact. First, by virtue of electoral pressures and differences in constituency bases, governments and central bankers differ systematically in their preferences over short-term trade-offs over unemployment and inflation. Relative to the preferences of central bankers, governments are more likely (for short- to medium-term electoral purposes) to avoid painful deflation and attempt to engineer "surprise" inflation that, if unexpected, can lead to a growth spurt in the near term. The political business cycle literature, in which governments attempt to stimulate growth just prior to elections, is built around this assumption, as are more recent models of the time-inconsistent preferences of governments. ${ }^{30}$ The basic insight of the latter approach is that governments with monetary discretion face perceived electoral incentives to renege on their earlier monetary commitments in order to achieve short-term growth. While they may promise monetary restraint, their desire to improve their economy's level of production drives them to attempt to engineer surprise short-term trade-offs along the Phillips curve. Where stimulation is anticipated, markets will adjust their contracts and investments to take the government's stimulatory policies into account, and the result will be inflation. ${ }^{31}$ Because governments

29. Eichengreen 1992, 206.

30. For an example of business cycle literature, see Nordhaus 1975.

31. See Kydland and Prescott 1977; Barro and Gordon 1983; and Blackburn and Christensen 1989. 
are assumed to have time-inconsistent preferences (it is rational, given their desire for growth, to renege on a promise of macroeconomic restraint), they have difficulty making credible commitments to price stability.

On the other hand, the preferences of central bankers are likely to be far more conservative with respect to tolerance for price inflation. The primary reason is that central bankers' background (and their primary constituency) is in banking. Banks, typically net creditors, expect to lose from unanticipated inflation and thus tend systematically to oppose it given the opportunity. ${ }^{32}$ The literature on credible monetary commitments cites providing governments with monetary credibility as one of the main functions of central banks-a function that is really only possible if central banks have no discretion over monetary policy or if the preferences of bankers differ systematically from those of governments. ${ }^{33}$ These distinct preferences have in fact been documented in a number of historical studies covering the years I examine here. ${ }^{34}$ Thus, the premise that central bankers generally are more highly averse to inflation than are elected politicians has a strong empirical as well as theoretical base.

Among the set of elected political officials, there is little reason to assume homogeneous preferences, however. Here I differ from many of the standard formulations of the time-inconsistency problem, for it is unnecessary and not particularly useful to assume that all governments would make the same choices along the Phillips curve were they given the opportunity to do so. Much of the political economy literature assumes that left-leaning governments who have working-class electoral bases prefer expansion and the risk of some inflation to price stability and low growth, though due to rational market expectations, they may not be able to realize those preferences. ${ }^{35}$ Therefore, while electoral and constituency considerations tend to undermine a government's inherent credibility for a low inflation policy, analysts have good reasons to suppose that the ability to establish a credible commitment to monetary restraint differs along party lines. If one purpose of a central bank is to enforce time-consistent preferences, then we should expect monetary policy to be more deflationary where governments' ex ante credibility is lowest. Governments whose political imperatives are more consistent with low inflation do not need externally supplied constraints; tighter monetary policy is therefore more likely when the left comes to power.

Additionally, while central banks have preferences that are more conservative than those of governments-especially governments of the left-their ability and willingness to provide monetary restraint are not unlimited. While most theories treat the independence of central banks as exogenous, bank officials know that they maintain independence at the sufferance of govern-

32. See Woolley 1984; Frieden 1988; and Epstein 1991.

33. Examples of this literature include Rogoff 1985; Lohmann 1992; and Cukierman 1992.

34. See Friedman and Schwartz 1963; and Epstein and Ferguson 1984.

35. See Kirschen et al. 1964; and Hibbs 1977. 
ments. Highly independent central banks are likely to moderate their behavior if they run the risk of provoking serious governmental resistance that can compromise their independence-a prediction that is not likely to apply to central banks in general. We should expect this knowledge to translate into behavior: the most independent banks should moderate their policies under governments that are unlikely to tolerate disinflation. In short, in a strategic situation in which independent monetary authorities are concerned to preserve their longer-term power, monetary policy is likely to be conditioned somewhat by the orientation of the government in power.

This framework suggests that an important part of the unwillingness of central banks to adjust to external imbalances is their desire to check politically induced inflation and preserve their long-term independence. Three predictions are:

(1) More independent central banks will be more deflationary and will place a higher priority on domestic price stability than will other central banks. Central bank independence is measured by the degree of political supervision and by politicians' ability to make frequent and important appointments. (See the data appendix for definitions, measures, and sources for all variables.)

(2) Central bank policy in general will be more deflationary under left-wing governments, whose ex ante credibility is thought to be lower. (Leftwing governments are designated as those in which parties of the left enjoyed sole rule or were the dominant party in a coalition.)

(3) If the more independent central banks act strategically, they will moderate their behavior under left-wing governments in order to preserve their longer-term independence.

\section{Control variables}

Scholars have advanced a number of competing explanations for the behavior of monetary authorities and insofar as possible, I have attempted to control for these. The first explanation is the hypothesis that monetary authorities simply are acting countercyclically: they conduct monetary policy neither with external considerations in mind nor in response to the needs of governmental credibility but only to counter the business cycle. Since the simple country-specific correlations strongly supported this hypothesis with respect to the money supply, it is critical that the present analysis take the business cycle into account. As above, I use changes in the index of industrial production in the previous period as an indicator of incipient price pressure. Strong growth in the previous period may be taken as a signal of impending pressures on the economy. An inverse relationship indicates countercyclical behavior with respect to both bank rate and the money supply. 
Second, I control for political instability, which often has been associated with inflationary expectations. It is not obvious a priori whether we should expect central banks to provide unstable governments with monetary credibility, but one can argue we should distinguish between governments that are unable, as opposed to merely reluctant, to avoid inflation. Extreme governmental instability can lead to the kind of policy incoherence that would doom to failure any attempt by monetary authorities to establish credibility externally. Under such circumstances, there is little point in the central bank providing credibility. "Monetary discipline" of unstable governments may, therefore, be weaker than that of governments of the left. Instability is measured as the number of significant cabinet turnovers in a given year. We should expect to find a weak negative relationship between instability and both dependent variables.

Third, in order to control for yet another source of government credibility, one version of the model also includes fiscal policy. Central banks may simply respond to changes in the budget balance-irrespective of party in power-in choosing monetary policies in the following period. Fiscal policy is measured as the rate of change in the government budget as a proportion of net national product in the previous period. If central banks were countering movements in fiscal policy, we would expect to see a strong positive relationship as deficits (negative movements in the budget) are met with monetary restraint (deflation). A negative relationship would indicate accommodation.

Fourth, it is possible that monetary authorities are attempting to manipulate the real exchange rate so as to maximize a country's trade competitiveness. One might expect that monetary authorities in highly trade-dependent countries prefer to keep a lower real exchange rate (disinflate domestic prices) to enhance export sales. The more important trade is to the economy, the more plausible is this expectation. To measure trade dependence, I use the total value of trade (imports plus exports) as a proportion of net national product. A negative relationship with both dependent variables would support the expectation.

Finally, two variables are included that give some purchase on the role of size and creditor status in pursuing a cooperative monetary policy. Hegemonic stability theory would suggest that powerful states (those with a strong stake in the stability of the international monetary system and whose monetary policies are likely to have significant consequences for other states in the system) pursue more cooperative policies on average. Stabilizing leadership, whether the single hegemon of Kindleberger's analysis or a cooperative consortium of the larger economies would seem to require the dominant economies to eschew monetary policies at either the deflationary or the inflationary extreme. If these characteristics indeed are associated with cooperative "systemically oriented" monetary policies, standard errors should be tight and coefficients small. Since larger traders and creditor states can be viewed as having the most at stake in, 
as well as largest influence on, the international monetary system, I use a country's share of total world trade and its net external creditor position as indicators of country size and position in the world economy. ${ }^{36}$

\section{Results}

\section{Generalized least squares results}

To test these relationships, time series cross-sectional data were pooled for fifteen countries for a period of fourteen years (1925-38). Pooling is both useful and justified in this case. It is useful because multivariate analysis would be difficult for this period unless one were willing to pool. It is justified since this is a first effort to make sense of the patterns of monetary adjustment that emerge during this period. While pooling data can uncover general relationships among the variables, it does sacrifice the ability to make interesting crosscountry comparisons. The two measures of monetary policy-the trichotomized bank rate and the manipulation of the money supply-were then used to test the above hypotheses. Generalized least-squares (GLS) analysis was employed, utilizing the Fuller-Battese method of estimation. ${ }^{37}$ (The trichotomized bank rate was also analyzed using an ordered probit model; the results are discussed briefly below and are consistent with the regression discussions that follow.) Since each country is likely to have some unique determinants of its monetary policy that are not part of the model presented here, fixed country effects were included in all specifications but one, but they are not reported here. One model (model 5) includes a dummy variable indicating the set of years (different for each country) in which a legal gold standard was in place, and model 6 reruns the tests on this subset of years only. A two-year moving average of the dependent variable was employed in the case of the money supply models to help smooth out some of the random disturbances and to produce a better fit. ${ }^{38}$

Tables 5 and 6 present the results of these analyses. With one exception, all versions of the model produced consistent results. Neither fixed effects nor

\section{Frieden 1988.}

37. Initially, ordinary least squares (OLS) were used to estimate the model, but due to a finding of slight one-period autocorrelation among the resulting error terms (0.33), and the possibility of heteroscedasticity (nine data points had to be estimated for Italy, France, and Hungary between 1925 and 1927, which is likely to introduce error in the early part of the series), I opted for a model in which the individual and time-specific random effects are added to the error term, and the parameters estimated efficiently using GLS. (The use of estimated data did not affect the analysis compared with runs that excluded those data.) Because the initial OLS results were somewhat inefficient but unbiased, the two procedures yield substantive results that are nearly identical.

38. When the model is estimated without the two-year moving average, the substantive results are nearly identical. The standard errors are smaller and the adjusted $R^{2}$ larger when the moving average is employed using OLS. (No $R^{2}$ is reported for the GLS method used here; however, for similar models using OLS estimation, $0.26 \leq R^{2} \leq 0.3$. 
systemic control variables substantively influenced their interpretation. ${ }^{39}$ These results confirmed the relationships originally seen in the simple correlations for several countries: central banks clearly were conducting their monetary policies in a way that countered business cycle pressures. Although the results are slightly weaker for the bank rate, a negative and highly statistically and substantively significant coefficient on change in the index of industrial production in the previous period indicates that as the economy began to expand, central banks tended to tighten interest rates and restrict monetary expansion to a greater extent than expected to achieve external balance. Conversely, when the economy slowed, monetary expansion was greater than should have been the case by the same criterion. This evidence suggests that central banks tended to respond to domestic economic conditions systematically, whether or not this may have been at cross-purposes to the problem of external adjustment and international stability.

However, more than the business cycle is at play here. The results provide strong evidence that the more independent central banks took policies that were systematically more deflationary than those taken by the more politically controlled banks and more deflationary than those required for external adjustment. Taking into consideration fixed effects, central bank independence was deflationary under both governments of the right and of the left. With respect to the measure of cooperative bank rate, a 1-point increase in the independence rating of the central bank could account for nearly one-quarter of the distance between our three categories for the bank rate (Table 5). With respect to the money supply, the coefficient for right governments was about -8 for the period as a whole but as high as -9.6 if one considers legal gold standard years only (Table 6 , model 6 ). The deflationary effects of central bank independence can also be estimated under left governments by combining the coefficients from independence and the interaction term. For example, in model 2 of Table 5, a 1-point move along the 8-point scale of central bank independence netted a coefficient of $(-0.255+0.145)=-0.11$. With respect to the money supply (Table 6), the net effect of the coefficients on independence and the interaction term ranged from -3.8 in model 2 to -4 in model 6 . These coefficients indicate that a 1-point move along the independence scale

39. Additionally, I ran the money supply model successively deleting one country at a time. The results were unaffected, except that the elimination of Germany tended to reduce the coefficient of central bank independence by about 2 points compared with model 5 . However, I assumed that had I been able to include Switzerland in the multivariate analysis (it was excluded because of lack of data on change in industrial production), a much stronger relationship between central bank independence and deflation would have been observed, since Switzerland's bank was both very independent and took very deflationary policies. To be certain results were not being driven by the inflationary outliers in Figures 1 and 3, model 2 was rerun for both dependent variables excluding Hungary, Italy, Japan, and Poland. The substantive relationships were unchanged; there was a slight increase in the size of the estimated coefficients and a tightening of standard errors for the money supply models when these countries were excluded from the analysis. Results for the bank rate were virtually unchanged. 
TABLE 5. Determinants of bank rate adjustment for fifteen countries, 1925-38 a

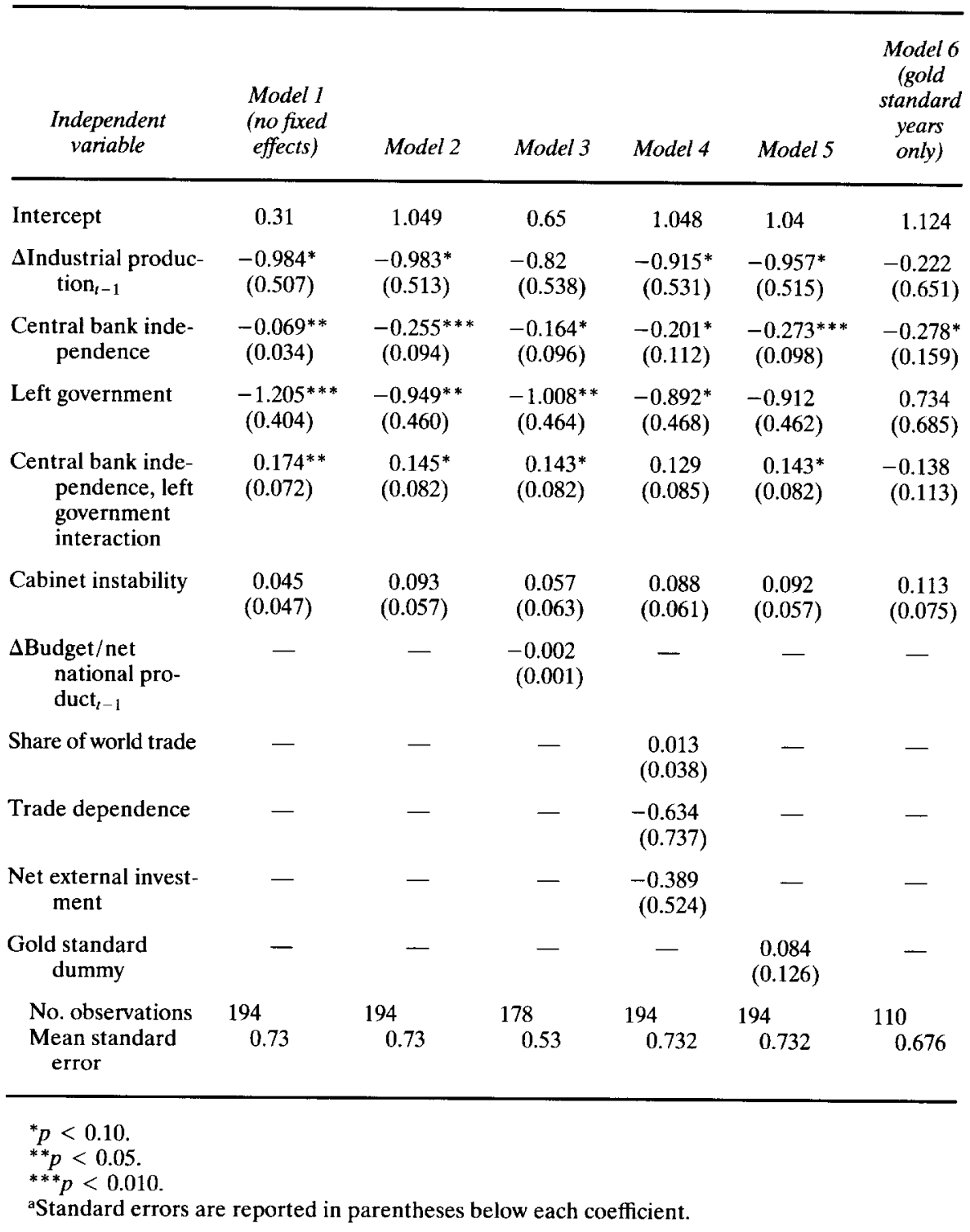

represents an important part of the distribution of the money supply variable (see Figure 2). This provides striking evidence of the deflationary choices of independent central banks. But there is also some evidence that the effect of central bank independence is conditioned by the political orientation of the 
TAB LE 6. Determinants of money supply adjustment for fifteen countries, 1925-38

\begin{tabular}{|c|c|c|c|c|c|c|}
\hline $\begin{array}{l}\text { Independent } \\
\text { variable }\end{array}$ & $\begin{array}{l}\text { Model l } \\
\text { (no fixed } \\
\text { effects) }\end{array}$ & Model 2 & Model 3 & Model 4 & Model 5 & $\begin{array}{l}\text { Model } 6 \\
\text { (gold } \\
\text { standard } \\
\text { years } \\
\text { only) }\end{array}$ \\
\hline Intercept & $11.097^{* * *}$ & $31.304^{* * *}$ & $47.44^{* * *}$ & $33.012^{* * *}$ & $35.29^{* * *}$ & $34.302 * * *$ \\
\hline $\begin{array}{c}\Delta \text { Industrial pro- } \\
\text { duction }_{-1}\end{array}$ & $\begin{array}{c}-41.372^{* * *} \\
(8.110)\end{array}$ & $\begin{array}{l}-39.213^{* * *} \\
(7.995)\end{array}$ & $\begin{array}{l}-44.92^{* * * *} \\
(8.39)\end{array}$ & $\begin{array}{c}-35.975^{* * *} \\
(8.285)\end{array}$ & $\begin{array}{l}-39.55^{* * *} \\
(8.56)\end{array}$ & $\begin{array}{c}-34.2^{* *} \\
(12.69)\end{array}$ \\
\hline $\begin{array}{l}\text { Central bank inde- } \\
\text { pendence }\end{array}$ & $\begin{array}{l}-3.112^{* * *} \\
(0.855)\end{array}$ & $\begin{array}{l}-8.400^{* * *} \\
(1.541)\end{array}$ & $\begin{array}{l}-12.17^{* * *} \\
\quad(2.38)\end{array}$ & $\begin{array}{l}-8.163^{* * *} \\
(1.753)\end{array}$ & $\begin{array}{l}-8.00^{* * *} \\
(1.811)\end{array}$ & $\begin{array}{c}-9.6^{* *} \\
(4.006)\end{array}$ \\
\hline Left government & $\begin{array}{l}-25.321^{* * *} \\
(7.386)\end{array}$ & $\begin{array}{l}-21.741^{* * *} \\
(7.576)\end{array}$ & $\begin{array}{l}-24.22^{* * *} \\
(7.43)\end{array}$ & $\begin{array}{l}-23.038^{* * *} \\
(7.632)\end{array}$ & $\begin{array}{r}-25.5^{* * *} \\
(7.642)\end{array}$ & $\begin{array}{r}-23.46^{*} \\
(12.91)\end{array}$ \\
\hline $\begin{array}{l}\text { Central bank inde- } \\
\text { pendence, left } \\
\text { government } \\
\text { interaction }\end{array}$ & $\begin{array}{l}4.910^{* * *} \\
(1.312)\end{array}$ & $\begin{array}{l}4.616^{* * *} \\
(1.352)\end{array}$ & $\begin{array}{l}5.20^{* * *} \\
(1.32)\end{array}$ & $\begin{array}{l}5.024^{* * *} \\
(1.378)\end{array}$ & $\begin{array}{l}5.27^{* * *} \\
(1.367)\end{array}$ & $\begin{array}{l}5.6^{* *} \\
(2.211)\end{array}$ \\
\hline Cabinet instability & $\begin{array}{l}1.599^{* * *} \\
(0.874)\end{array}$ & $\begin{array}{l}2.571^{* * *} \\
(0.906)\end{array}$ & $\begin{array}{l}1.78^{*} \\
(0.975)\end{array}$ & $\begin{array}{l}2.445^{* *} \\
(0.948)\end{array}$ & $\begin{array}{r}2.51^{* *} \\
(0.944)\end{array}$ & $\begin{array}{l}1.9 \\
(1.35)\end{array}$ \\
\hline $\begin{array}{l}\Delta \text { Budget/net } \\
\text { national pro- } \\
\text { duct }_{t-1}\end{array}$ & - & - & $\begin{array}{c}-0.025 \\
(0.023)\end{array}$ & - & - & - \\
\hline $\begin{array}{c}\text { Share of world } \\
\text { trade }\end{array}$ & - & - & - & $\begin{array}{c}-1.371^{* *} \\
(0.579)\end{array}$ & $\begin{array}{c}-1.24^{* *} \\
(0.611)\end{array}$ & $\begin{array}{l}-1.5 \\
(19.98)\end{array}$ \\
\hline Trade dependence & - & - & - & $\begin{array}{r}-15.779 \\
(9.904)\end{array}$ & $\begin{array}{l}-0.727 \\
(11.97)\end{array}$ & $\begin{array}{l}-8.79 \\
(17.55)\end{array}$ \\
\hline $\begin{array}{l}\text { Net external } \\
\text { investment }\end{array}$ & - & - & - & $\begin{array}{l}14.541 \\
(8.886)\end{array}$ & $\begin{array}{l}13.95 \\
(8.5)\end{array}$ & $\begin{array}{r}19.97^{*} \\
(11.52)\end{array}$ \\
\hline $\begin{array}{c}\text { Gold standard } \\
\text { dummy }\end{array}$ & - & - & - & - & $\begin{array}{c}-4.74^{* *} \\
(2.13)\end{array}$ & - \\
\hline $\begin{array}{l}\text { No. observations } \\
\text { Mean standard } \\
\text { error }\end{array}$ & $\begin{array}{l}209 \\
150.15\end{array}$ & $\begin{array}{l}209 \\
144.05\end{array}$ & $\begin{array}{l}190 \\
134.04\end{array}$ & $\begin{array}{l}209 \\
142.98\end{array}$ & $\begin{array}{l}209 \\
140.01\end{array}$ & $\begin{array}{l}115 \\
151.66\end{array}$ \\
\hline
\end{tabular}

${ }^{*} p<0.10$.

${ }_{* *}^{* *}<<0.05$.

${ }^{* * *} p<0.010$.

a Standard errors are reported in parentheses below each coefficient.

government in power. With one exception (Table 6, model 6) central bank independence produced somewhat less deflationary policies under left governments than it did under right governments. While much more work needs to be done to understand the dynamics that might lead to such an outcome, this fits 
an interpretation that emphasizes the strategic relationship between governments and so-called independent central banks, with the latter willing to moderate monetary policy in order to preserve their long-term independence.

Finally, central banks in general clearly used their monetary policy to constrain-or, in the language of the time-inconsistency models alluded to above, to "provide credibility" for-left governments. The presence of a left government deflates the outcome on bank rate approximately one whole category (the coefficient on government orientation ranges between -1.2 and -0.89 for models $1-5$ in Table 5), while the difference in the conduct of monetary policy under left and right governments could account for a difference of between 22 and 25 points in our measure of cooperative monetary policy adjustment. The negative sign indicates that central bank policies were far more deflationary under left governments than under right governments. This outcome is not easily attributable to the fact that left governments most often came to power under the deflationary conditions of the 1930s, since this analysis already has controlled for the direction of the business cycle.

Nor did the inclusion of a "depression dummy" (1931-1938; results not reported here) make any difference to the strong negative relationship between the presence of left government and deflationary monetary policy (or any of our other results, except to weaken the impact somewhat of the business cycle variable). Furthermore, this partisan effect is not washed out by controlling for changes in fiscal policy in the previous period (to which these policy choices bore no systematic relationship). As Figure 4 shows for the money supply, central banks were far more constrictive under left governments in the 1930s than they were under right governments. This pattern fits an interpretation that, especially after 1932, monetary authorities feared the inflationary expectations associated with left governments' policies and tried to provide reassurance to markets by tightening monetary constraints. (The erratic outcome in the $1920 \mathrm{~s}$ is due largely to the existence of very few left governments. In 1927 only Finland and in 1928 only Germany had governments that could be considered "left.")

Instability did not prove to have the weak negative effect hypothesized above. Central banks did not appear to try to constrain or provide credibility for unstable governments. On the contrary, cabinet instability is almost certainly correlated with a more inflationary money supply policy (although substantively the relationship is quite small) and is in the inflationary direction (though not statistically significant) with respect to the bank rate as well. One cabinet change could be expected to produce a monetary policy that was only about 2 points more inflationary than the ideal (Table 6), a difference that would seem minor even in the presence of significant instability. These results suggest that to the extent that central banks strategically attempted to provide governmental credibility or to constrain governments, they played the deflation card only when they had some hope of altering governments' behavior and markets' expectations. 


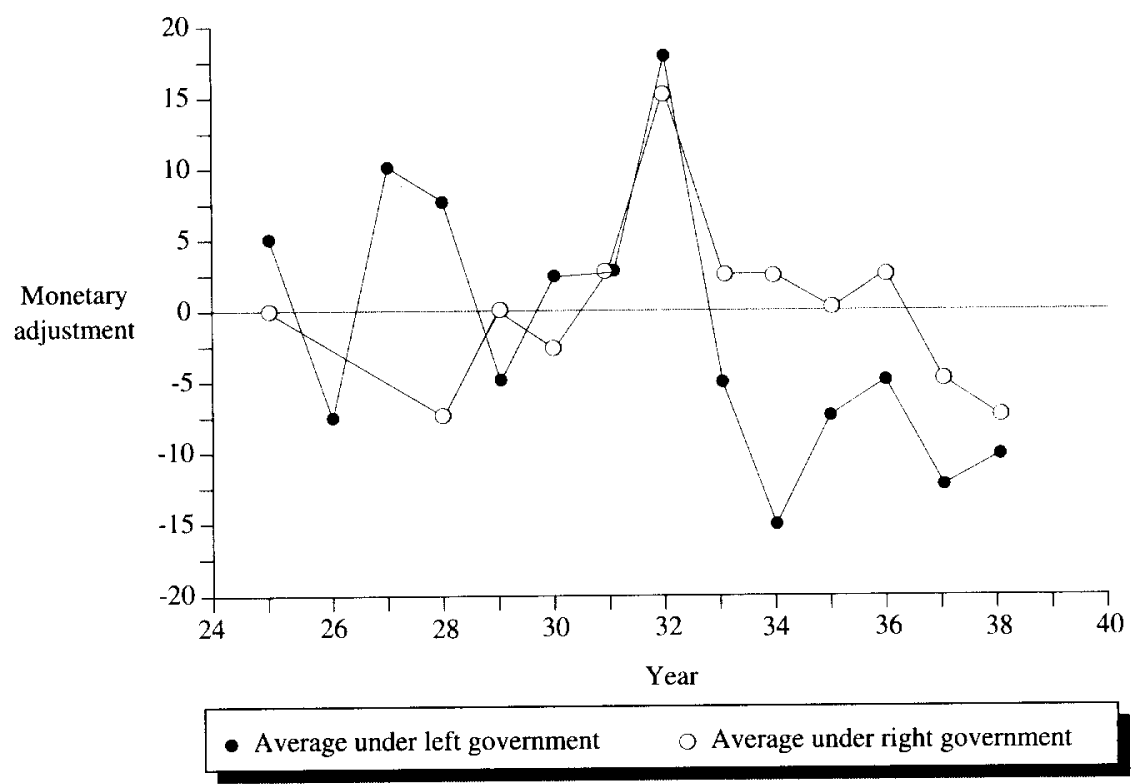

FIG URE 4. Monetary adjustment by central banks under left versus right governments for fifteen countries, 1925-38

Next, consider the impact of the more systemic or structural variables that have been the focus of the international political economy literature. The data show virtually no relationship between these systemic variables and a cooperative bank rate. With respect to money supply manipulation, the most significant of the control variables would appear to be share of world trade. In models 4 and 5, larger traders almost certainly took more deflationary policies than did smaller traders (though when the sample is reduced to legal gold standard years alone this effect washed out, more in keeping with the original hypothesis). Nonetheless when the interwar years as a whole are considered, the effect was substantively significant as well: holding all other variables at their mean, the largest trader in our sample (Great Britain, with an average of just over 17 percent of world trade for the period) would have taken money supply policies that were 17 points more deflationary than the average-sized trader in the sample. This evidence is inconsistent with a story of hegemonic leadership in international monetary relations. Also, central banks of the more trade-dependent economies probably did tend to take more deflationary money supply policies (with $p<0.12$ in model 4 ), though once again, this would appear to be true only if we analyze the period as a whole. In substantive terms, the estimate in model 4 would mean that, holding all other variables at their means, the most self-sufficient country in the sample (the United States, with only 8.2 percent of its economy traded) would pursue a policy that was about 6 points more inflationary than a country whose openness was at the sample 
TABLE 7. Ordered probit results: probability of deflationary, cooperative, or inflationary bank rate policy ${ }^{\mathrm{a}}$

\begin{tabular}{|c|c|c|c|}
\hline $\begin{array}{l}\text { Independent } \\
\text { variable }\end{array}$ & $\begin{array}{l}\text { Ordered } \\
\text { probit } \\
\text { coefficient }\end{array}$ & $\begin{array}{l}\text { Standard } \\
\quad \text { error }\end{array}$ & $\operatorname{Pr}>x$ \\
\hline Intercept 1 & 1.115 & 0.938 & 0.234 \\
\hline Intercept 2 & 1.306 & 0.120 & - \\
\hline$\Delta$ industrial production $_{t-1}$ & -0.018 & 0.008 & $0.032^{* *}$ \\
\hline Central bank independence & -0.438 & 0.202 & $0.031^{* *}$ \\
\hline Left government & -1.718 & 0.759 & $0.024^{* *}$ \\
\hline Central bank independence, left government interaction & 0.260 & 0.134 & $0.052^{*}$ \\
\hline Cabinet instability & 0.159 & 0.093 & $0.089^{*}$ \\
\hline$\Delta B u d g e t /$ net national product ${ }_{t-1}$ & 0.002 & 0.002 & 0.226 \\
\hline $\begin{array}{l}\text { No. observations } \\
\text { Log likelihood for normal }\end{array}$ & $\begin{array}{c}196 \\
-190.67\end{array}$ & & \\
\hline
\end{tabular}

${ }^{a}$ Analogous to Table 5, model 3, rerun using an ordered probit specification. Includes fixed country effects.

${ }^{*} p<0.10$.

${ }^{* *} p<0.05$.

mean. This result provides evidence of trade-related reasons for sterilization: a lower real exchange rate could improve a country's ability to sell its goods in foreign markets.

\section{Ordered probit results}

Because the bank rate is a trichotomized dependent variable, an ordered probit specification is more appropriate than GLS. This procedure allows us to model the probabilities $(P)$ of the bank rate falling into any one category (inflationary, deflationary, or cooperative).$^{40}$

Table 7 presents the results of the ordered probit model. These closely

40. This probability is given by:

$$
\begin{aligned}
& P_{\text {deflationary }}=\Phi\left(X^{\prime} b\right) \\
& P_{\text {cooperative }}=\Phi\left(X^{\prime} b+a_{1}\right)-\Phi\left(X^{\prime} b\right) \\
& P_{\text {inflationary }}=1-\Phi\left(X^{\prime} b+a_{2}\right)
\end{aligned}
$$

where $\Phi\left(\mathrm{X}^{\prime} b\right)$ is the standard normal cumulative distribution, and $a_{1}$ and $a_{2}$ are additional parameters denoted as intercepts in the reported output. 
TABLE 8. Interpretation of ordered probit results for bank rate policy: effects of central bank independence ${ }^{\mathrm{a}}$

Value of central bank independence

\begin{tabular}{lccccccc}
\cline { 2 - 7 } \multicolumn{1}{c}{$\begin{array}{c}\text { Probability } \\
\text { of }\end{array}$} & 2 & 3 & 4 & 5 & 6 & 7 & 8 \\
\hline Inflationary response & 0.55 & 0.40 & 0.27 & 0.16 & 0.08 & 0.04 & 0.02 \\
Cooperative response & 0.37 & 0.45 & 0.48 & 0.46 & 0.38 & 0.28 & 0.18 \\
Deflationary response & 0.08 & 0.15 & 0.25 & 0.38 & 0.53 & 0.68 & 0.80 \\
\hline
\end{tabular}

${ }^{a}$ All other variables were held at their mean.

reflect the findings of the above regressions. Table 8 offers an interpretation of the probit results for the central bank independence variable: it provides the calculated probabilities of choosing a deflationary, cooperative, or inflationary bank rate response to movements in the balance of payments with all other variables held constant (i.e., at their means). Based on these results, it is clear that the impact of central bank independence is large. The probability of choosing an overly deflationary bank rate policy is only 8 percent for the most politically dependent bank in the group but is about 80 percent for the most politically independent bank.

Furthermore, the effects of central bank independence appear to be asymmetric. Once again, holding all other variables at their means, the most independent banks are much more likely to be deffationary ( 80 percent probability) than the most politically dependent ones are to be inflationary (55 percent probability). The ordered probit results also allow us to focus on the crucial cooperative region of the distribution. Here, the results are eyeopening: the more politically controlled central banks were much more likely to choose bank rate policies that fell in the cooperative region than were the politically independent central banks. The results produced here indicate that central banks under the most political control (rated 2) were more than twice as likely as those that were highly independent (rated 8) to choose cooperation. Indeed, the very high probabilities of adjusting bank rate according to gold standard norms among central banks with only a modest-to-moderate degree of political independence is striking. Countries such as Austria, Hungary, Norway, and Sweden, whose central banks were subject to an important degree of regular parliamentary oversight, were most likely to follow bank rate policies that countered gold flows. By contrast, the U.S. Federal Reserve Bank in the 1930s and the central banks of England, France, and the Netherlands were far more likely to respond to gold inflows with further increases in the bank rate, to the deflationary detriment of the rest of the world. 


\section{Discussion and conclusions}

The purpose of this article has been to consider systematically why the gold standard was so fragile during the interwar years and the implications this may have for international monetary stability in Europe today. Recent research has suggested that the gold standard was a highly deflationary monetary regime that served to frustrate growth and spread depression..$^{41}$ Ben Bernanke, for one, has argued that under a gold standard it makes sense to talk about a "world money supply," which collapsed precipitously in the 1930s. ${ }^{42}$ An important part of this collapse was the fact that interest rates were not used to counter gold inflows and, moreover, that gold reserves and other foreign assets were being sterilized in a few central banks (notably those of France and the United States) who refused to expand their (and thus, the system's) monetary base. Yet deficit countries were constrained to raise interest rates and contract their money supply or else face devaluation. The net impact was a severe drop in the "world money multiplier," which resulted in the transmission of deflation throughout the system and a rapid erosion of the confidence necessary to maintain fixed rates and gold convertibility. This finally toppled the system itself. In his postmortem of the interwar gold standard, Keynes referred to its deflationary bias and blamed the system of rules that permitted countries experiencing gold inflows to refrain from making the necessary policy adjustments.

But was it the rules themselves or their selective implementation that destabilized the system? And if the latter, then what explains their selective implementation? The most obvious explanation is concern for domestic price stability. All the evidence provided here suggests that willingness to play by the rules was strongly influenced by the direction of the business cycle in the previous period. This is consistent with an interpretation that central banks had their eye on potential domestic price pressures. Where growth was strong in the previous period, they sought to dampen inflationary expectations in the next.

Such behavior complicated the problem of external adjustment, however. External adjustment required monetary policy to be conducted in response to gold flows and changes in other assets on the central bank's foreign account. Gold inflows were supposed to elicit monetary easing, even if growth had picked up in the previous period. Central banks' concern with domestic price stability could potentially conflict with the demands of external adjustment. And while it may be astounding to present-day readers to learn that concerns over price pressures in 1936 were partly responsible for the U.S. program of gold sterilization that followed, wherever nipping inflation in the bud was the monetary authority's highest concern, the bias was for externalization of deflationary policy onto the rest of the world.

41. Eichengreen 1992.

42. Bernanke 1993. 
The central finding of this research is that central bank independence contributed to the deflationary bias in the interwar monetary regime. Because they were concerned primarily with domestic prices and because they tended to have preferences that were more conservative than those of governments, independent central bankers took monetary policy actions that were more contractionary than were justified for external adjustment. The probit results provided further insights into this relationship: when comparing the effect of central bank independence on choosing a deflationary bank rate with the effect of political dependence on choosing an inflationary one, the probability of the former was higher than the latter, ceteris paribus. Another important finding is that central banks as a group were far more contractionary under left governments than they were under right governments, even when controlling for fiscal policy changes in the previous period. Once again, this is easy to interpret in terms of the commitment to price stability and the perceived need to "constrain," or in the terms of time-inconsistency models, to provide credibility for governments whose partisan orientation weakened their ex ante credibility. Indeed, history is replete with interesting accounts of the horror that left-wing macroeconomic experiments and social policies instilled in orthodox financial circles in the 1930s. With domestic prices their main concern, one can readily understand the strong evidence presented here of central bankers' efforts to constrain what were perceived to be the more unorthodox governments of the left.

A third finding is somewhat counterintuitive in the absence of further case-oriented research: while central bank independence is associated with deflation, the effects seem slightly stronger under right-wing than left-wing governments. One interpretation is that central bank independence does not totally free the monetary authority from political pressure: the government holds the trump (revocation of independence), and banks with high degrees of independence moderate their behavior to preserve their long-term independence. But to be convincing, this argument would have to be buttressed with evidence that left governments were perceived to be more likely than right governments to circumscribe banks' independence (which appears to be true if one looks only at democracies such as France under the Front Populaire). Research on the rules for institutional change in each case would also be useful, for the party difference may not be robust when the ease or difficulty of altering the bank's independence status is taken into account. All that can be said at this point is that central bank independence has deflationary effects across the political spectrum; further research may shed light on why there appears to be some monetary accommodation among the more independent banks under left governments. However the notion that banks might be engaging in strategic behavior to preserve long-run independence is not far-fetched.

These findings are consistent with pieces of evidence from other fixed exchange-rate regimes as well. Research on the Bretton Woods period also 


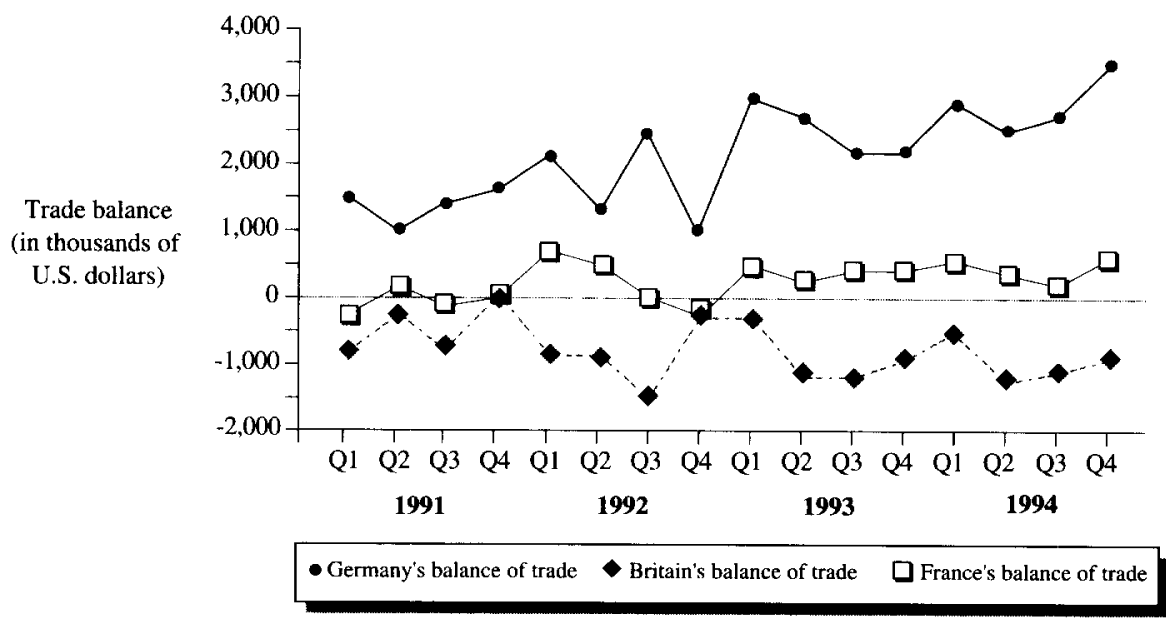

FIGURE 5. Britain's, France's, and Germany's trade balances with Europe, in thousands of U.S. dollars (up to 1993 net trade balance is with the twelve countries of the European Community, and for 1993-94 net trade balance is with the fifteen countries of the European Union)

Source. Organization for Economic Cooperation and Development (OECD), Monthly Statistics of Foreign Trade (Paris: OECD Statistics Directorate, various issues).

suggests that the independent Bundesbank rarely took monetary policies to adjust to its surplus position. Rather, the only variable that seemed to elicit a response from the Bundesbank during that period was growth in the index of industrial production, to which-consistent with the above findings-it responded countercyclically. ${ }^{43}$ The Bundesbank's actions, of course, did not upset the Bretton Woods system of fixed exchange rates, since they occurred during a period of high employment and sustained growth in which the United States was taking inflationary actions under a fairly permissive Federal Reserve. The deflationary systemic consequences of German sterilization in the 1960 s and 1970 s were therefore unlikely to matter to any significant degree.

The same cannot be said about the decisions of the German monetary authorities under the ERM. Bundesbank policy dominates the European system to approximately the same extent that the United States has dominated the international monetary system for much of this century. And Germany's trade surplus with the rest of Europe contrasts with France's near balance and the United Kingdom's deficit (see Figure 5). In a period of systemic slow growth and low inflation (between 1990 and 1993, the growth rate of the European gross national product averaged only about 2 percent per year, inflation slowed and averaged about 4 percent per year, and unemployment 
crept upward to about 8 percent among Organization for Economic Cooperation and Development members), the policies of one significant surplus country aimed at keeping perceived domestic inflationary pressures in check has the greatest tendency to export deflation and crack open exchange rate parities. ${ }^{44}$ In the ERM crises of 1992 and 1993, as Michael Mussa and Morris Goldstein noted, "it is hard to argue that in countries already in deep recession and with inflation in abeyance, higher interest rates would have been either credible or desirable. The capital flows that took place during these crises clearly paid attention to this situation." ${ }^{45}$ Under these conditions, the tension between external balance-of-payments adjustments and domestic monetary policy preferences are greatest and the stability of the international monetary system is most subject to deflationary pressures and/or collapse, as history shows.

Of course, this is not a claim that the 1990 s are economically or politically equivalent to the mid-1930s, much less a claim that one could develop a single model for monetary policy choice that would fit a neat regression line throughout the twentieth century. Too much has changed for such facile comparisons to ring true. Democratically elected governments-independent central banks or no-will not endure the deflation that many did in the 1930s in the name of monetary stability; they will exit the exchange rate system sooner than they did in the 1930s. Many more have gladly accepted floating exchange rates over a significant loss of monetary autonomy. Furthermore, based on fifty years of relatively benign experience with left-wing governments, we should not necessarily expect the strong monetary discipline of left-wing parties the interwar data indicate. Finally, the conduct of monetary policy is sensitive to whatever historical lesson is most recent: the postwar lesson of the 1920s was that inflation had to be controlled, making it the focus of policymaking for monetary authorities well into the 1930 s. (Indeed, it may be that a similar lesson has been drawn in some circles from the inflation of the 1960 s and especially of the $1970 \mathrm{~s}$.)

Yet as the advanced industrialized countries tried to emerge from the recession of the early 1990 s, conditions in their essentials were similar enough to the earlier period to warrant one important and often overlooked conclusion: even when governments wish to cooperate with one another to maintain stable exchange rates, independent central banks can frustrate this goal..$^{46}$ At a minimum, this research should temper the recent enthusiasm in policy and academic circles for central bank independence. If central bank independence contributed to the deflationary bias in the interwar monetary regime, and if central banks in general used monetary instruments to constrain certain

44. Organization for Economic Cooperation and Development, Main Economic Indicators, various issues.

45. Mussa and Goldstein 1993, 291.

46. Hefeker 1994, 396-97. On the commitment of Chancellor Kohl and the Christian Democrats in Germany to European integration and its corollary, EMU, see Economist, 27 July 1991, 50; Financial Times (London), 8 December 1991, 7-8; and Derbyshire 1987. 
"loose" governments-so much so that they refused to take externally cooperative adjustment policies - then we should examine carefully the relationship between domestic monetary institutions and international monetary regimes more generally. Policymakers and academics may have to think critically about designing domestic monetary institutions that can respond to the demands of both internal price stability and external adjustment. If governments want stable exchange rates-the declaratory policy of the Tripartite Agreement of 1936 and today's European Monetary System-then more thought might profitably be given to how to design domestic monetary institutions that can stabilize prices subject to politically negotiated international understandings of cooperative monetary behavior. Political independence should not be the sole criterion by which to judge the institutional soundness of a central bank, as the bulk of the recent research on the effects of central bank independence seems to suggest. Indeed, the probit results indicate that a significant degree of political control is more consistent with high probabilities of choosing internationally cooperative monetary policies than is extreme central bank independence.

While much remains to be done, this research should cause us to think carefully about the assumption that independent central banks are an institutional panacea for monetary instability. Paradoxically, central bank independence may be inimical to international monetary and economic stability, at least under some conditions. Independent monetary authorities give top priority to domestic price stability. Yet a fixed exchange-rate regime implies conducting monetary policy with a view to maintaining some degree of external balance and systemic liquidity. Where monetary authorities pursue the former single-mindedly (as perhaps the Bundesbank has done in the 1990s, with negative consequences for the European Monetary System), the results can be destabilizing for the international monetary regime. ${ }^{47}$

\section{Appendix}

\section{Dependent variables}

Central bank rate adjustment. A trichotomized variable that indicates whether bank rate movements were inflationary (1), deflationary $(-1)$, or cooperative $(0)$ in response to changes in the foreign assets, including gold reserves and foreign exchange, of the central bank in the previous period. Policy was rated as cooperative if foreign assets and bank rate in the following period moved in opposite directions; as inflationary if outflows were followed by reduction in bank rate; and as deflationary if inflows were followed by bank rate reduction in the following period. Bank rate data are from League of Nations, Monthly Bulletin of Statistics, various issues. Data on foreign assets of the central banks are from Nurkse 1944, appendix 4, 237-40. 
Central bank money supply adjustment. Calculated as the percentage change in domestic assets (primarily domestic bonds) of the central bank of each country each year $\times 0.3$ minus the percentage change in the foreign assets of the central bank of each country each year for the previous period (\% $\%$ domestic assets $\times 0.3-\% \Delta$ foreign assets). Two-year moving averages are used in the multivariate analysis. Data are from Nurkse 1944, appendix 4, 237-40.

\section{Explanatory variables}

Change in the index of industrial production. Change in real industrial output for each country from year to year $(1937=100)$. Data are from Mitchell 1980 Table E1, $356-57$.

Central bank independence. An 8-point scale was devised combining two dimensions of formal independence: (1) the degree of political control over appointments, and (2) the degree of political supervision over bank activities. The higher the rating of the central bank, the more independent from formal political control (according to a reading of its statutes or constitution). The basic measure was improved by changing ratings as independence was altered over time, e.g., in the cases of the United States, Italy, and Germany. For specific criteria and sources, see Simmons 1994, 295.

Government orientation (left versus right government). A dummy variable that distinguishes between cases of no or minor left participation (e.g., as a small supporting member of a coalition government) coded as 0 and cases of significant left participation (e.g., as a coalition leader or sole left leadership), coded as 1. Data are from Flora 1983, 153-89; Rose 1974; and McHale and Skowronski 1983.

Cabinet instability. The number of times each year in which at least 50 percent of the cabinet changed, or else the Prime Minister was replaced. Data are from Banks, segment 1 , field $\mathrm{M}$.

Change in budget/net national product (NNP). The numerator, the budget balance, is calculated as the difference between total tax receipts (total ordinary government revenue exclusive of loan receipts) and total central government expenditures (including interest payments on loans). For some countries, the series contains receipts from public enterprises. The denominator, NNP, is a widely used prewar measure of national wealth. The most important distinction between NNP and gross national product (GNP) is that the latter does not include the cost of capital depreciation. Hence NNP is generally 5-10 percent less than GNP. Where NNP data were available only in constant prices (France and Czechoslovakia), these were converted to current prices using yearly price ratios. For countries for which only GNP data were available (Austria, Czechoslovakia, Italy, Japan, Norway, Sweden). GNP figures were multiplied by 0.925 to obtain an approximate NNP. Data for both the numerator and the denominator are from Mitchell 1980. For budget balance data, see Tables $\mathrm{H} 4$ and $\mathrm{H} 5,700-703$ and 716-26, respectively.

In an effort to locate comparable net figures, supplementary data were gathered and comparisons made with the country-specific statistics. For Britain, comparison data are from Mitchell 1962. For Denmark comparison data are from Bjerke table 10, 123-151. 
For France, the constant NNP was converted into current prices using price indices in Sauvy 1984, table 8.1, 347. For Japan, comparison data are from Tsuru and Ohkawa 1953, 19-44. For the United States, comparison data are from U.S. Bureau of the Census various years.

Share of world trade. Data are from Banks 1971, segment 5, field D. Sections of the series for Austria, Czechoslovakia, Hungary, and Germany were estimated. See Simmons 1994, 296.

Trade dependence. Total trade (imports plus exports) as a proportion of NNP. Data are from Mitchell 1975, table F1, 493-97.

Net external investment. Measured as a dummy variable that separates net debtors (0) from net external creditors (1). This measure varies by country but not over time. Data are from League of Nations 1932, 39-40, and UN Secretariat 10-12 and 18-20.

\section{References}

Bade, Robert, and Michael Parkin. 1982. Central bank laws and monetary policy. University of Western Ontario. Typescript.

Banks, Arthur S. 1971. Cross-polity time series data. Cambridge, Mass.: MIT Press.

Banaian, King, Leroy O. Laney, and Thomas D. Willett. 1983. Central bank independence: An international comparison. Economic Review (Federal Reserve Bank of Dallas), March 1-13.

Barro, Robert J., and David B. Gordon. 1983. A positive theory of monetary policy in a natural rate model. Journal of Political Economy 91:589-610.

Bernanke, Ben. 1993. The world on a cross of gold: Review of golden fetters. Joumal of Monetary Economics 31:251-67.

Bernhard, William T. 1994. Governments, parties, and bureaucratic structure: Explaining central bank independence. Paper presented at the ninetieth annual meeting of the American Political Science Association, 1-4 September, New York.

Bjerke, Kjeld. 1955. "The national product of Denmark." In Income and wealth. Series 5. Cambridge: Bowes and Bowes.

Bloomfield, Arthur. 1959. Monetary policy under the intemational gold standard: 1880-1914. New York: Federal Reserve Bank of New York.

Clark, William Robert. 1994. Party structure, regime stability, and the government supply of central bank independence. Paper presented at the ninetieth annual meeting of the American Political Science Association, 1-4 September, New York.

Clarke, S.V.O. 1967. Central bank cooperation, 1924-1931. New York: Federal Reserve Bank of New York.

Cukierman, Alex. 1992. Central bank strategy, credibility, and independence: theory and evidence. Cambridge, Mass.: MIT Press.

Cukierman, Alex, Steven B. Webb, and Bilin Neyapti. 1992. Measuring the independence of central banks and its effect on policy outcomes. World Bank Economic Review 4:353-98.

Dam, Kenneth. 1982. The rules of the game: Reform and evolution in the international monetary system. Chicago: University of Chicago Press.

Davidson-Schmich, Louise K. 1994. German policy and the recent ERM crises. Department of Political Science, Duke University, Durham, North Carolina. Typescript.

Derbyshire, Ian. 1987. Politics in West Germany: From Schmidt to Kohl. Cambridge: Chambers.

Eichengreen, Barry, ed. 1985. The gold standard in theory and history. New York: Methuen. 
1989. International monetary instability between the wars: Structural flaws or misguided policies? NBER working paper no. 3124, National Bureau of Economic Research, Cambridge, Mass.

1992. Golden fetters: The gold standard and the great depression, 1919-1939. Oxford: Oxford University Press.

Epstein, Gerald. 1991. Profit squeeze, rentier squeeze, and macroeconomic policy under fixed and flexible exchange rate regimes. Economies et Sociétés 25 (November-December): 219-57.

1992. Political economy and comparative central banking. Review of Radical Political Economics 24:1-30.

Epstein, Gerald, and Thomas Ferguson. 1984. Monetary policy, loan liquidation, and industrial conflict: The Federal Reserve and the open market operations of 1932. Joumal of Economic History 44:957-83.

Flora, Peter. 1983. State, economy, and society in Western Europe, 1815-1975. Frankfurt am Main: Campus Verlag.

Fratianni, Michele, and Haizhou Huang. 1992. Central bank independence and optimal conservativeness. Working paper in economics no. 92-030, Indiana University, Bloomington.

Frieden, Jeffry. 1988. Capital politics: Creditors and the international political economy. Journal of Public Policy 8:265-86.

Friedman, Milton, and Anna Schwartz. 1963. A monetary history of the United States, 1867-1960. Princeton, N.J.: Princeton University Press.

Gowa, Joanne. 1983. Closing the gold window. Ithaca, N.Y.: Cornell University Press.

Grilli, Vittorio, Donato Masciandaro, and Guido Tabellini. 1991. Political and monetary institutions and public financial policies in the industrial countries. Economic Policy 13:342-92.

Hefeker, Carsten. 1994. German monetary union, the Bundesbank, and the EMS collapse. Banca Nazionale del Lavoro Quarterly Review 191:379-98.

Hibbs, Douglas A. 1977. Political parties and macroeconomic policy. American Political Science Review 71:1467-87.

Keohane, Robert O. 1984. After hegemony: Cooperation and discord in the world political economy. Princeton, N.J.: Princeton University Press.

Keynes, John Maynard. 1980. Activities 1940-1944: The collected writings of John Maynard Keynes. Vol. 25. Edited by Donald Moggridge. Cambridge: Cambridge University Press.

Kindleberger, Charles P. 1986. The world in depression, 1929-1939. Berkeley: University of California Press.

Kirschen, E. S., J. Bernard, H. Besters, F. Blackaby, D. Eckstein, J. Faaland, F. Hartog, L. Morissens, and E. Tosco. 1964. Economic policy in our time, vol. I: general theory. Amsterdam: North Holland.

Kydland, Finn, and Edward C. Prescott. 1977. Rules rather than discretion: The inconsistency of optimal plans. Journal of Political Economy 85:473-91.

League of Nations. 1932. World Economic Survey, 1931-1932. Geneva: Economic Intelligence Unit.

Lohmann, Susanne. 1992. Optimal commitment in monetary policy: Credibility versus flexibility. American Economic Review 82:273.

Marsh, David. 1992. The Bundesbank: The bank that rules Europe. London: William Heinemann.

Maxfield, Sylvia. 1994. The politics of central banking in developing countries. Department of Political Science, Yale University. Typescript.

McHale, Vincent E., and Sharon Skowronski, eds. 1983. Political parties of Europe. Greenwood Historical Encyclopedia of the World's Political Parties. Westport, Conn.: Greenwood Press.

Michaely, Michael. 1971. Responsiveness of demand policies to balance of payments: Postwar patterns. New York: National Bureau of Economic Research.

Mitchell, B. R. 1962. Abstract of British historical statistics. Cambridge: Cambridge University Press. . 1980. European Historical Statistics, 1750-1975. 2d rev. ed. New York: Facts on File.

Mlynarski, Feliks. 1929. Gold and central banks. New York: Macmillan.

Mussa, Michael, and Morris Goldstein. 1993. The integration of world capital markets. In The 
Federal Reserve Bank of Kansas City, changing capital markets: implications for monetary policy. Symposium. Kansas City, Mo.: Federal Reserve Bank of Kansas City.

Nordhaus, William. 1975. The political business cycle. Review of Economic Studies 42:169-90.

Nurkse, Ragnar. 1944. International currency experience: Lessons from the intenwar period. Geneva: League of Nations, Economic, Financial, and Transit Department.

Odell, John. 1982. Markets, power, and ideas. Princeton, N.J.: Princeton University Press.

Oye, Kenneth A. 1992. Economic discrimination and political exchange. Princeton, N.J.: Princeton University Press.

Rogoff, Kenneth. 1985. The optimal degree of commitment to an intermediate monetary target. Quarterly Joumal of Economics 100:1169-89.

Rose, Richard, ed. 1974. Electoral behavior: A comparative handbook. New York: Free Press.

Sauvy, Alfred. 1987. Histoire economique de la France entre les deux guerres (Economic history of France between the two wars). Paris: Economica.

Simmons, Beth A. 1994. Who adjusts? Domestic sources of foreign economic policy during the interwar years, 1924-1939. Princeton, N.J.: Princeton University Press.

Snidal, Duncan. 1985. The limits of hegemonic stability theory. International Organization 39:579-614.

Triffin, Robert. 1960. Gold and the dollar crisis. New Haven, Conn.: Yale University Press.

U. K. Parliament. 1918. First interim report of the Committee on Currency and Foreign Exchanges After the War [Cunliffee Committee]. Cd. 9182.

. 1931. Report of the Committee on Finance and Industry [Macmillan Committee], Cmd. 3897.

United Nations (UN) Secretariat. 1949. International capital movements during the interwar period. New York: UN Department of International Affairs.

U.S. Bureau of the Census. Various years. Statistical abstract of the United States. Washington, D.C. Walter, Andrew. 1991. World power and world money. Cambridge: Cambridge University Press.

Willis, Henry Parker. 1936. The theory and practice of central banking. New York: Harper and Brothers.

Woolley, John T. 1984. Monetary politics: The Federal Reserve and the politics of monetary policy. Cambridge: Cambridge University Press.

Yeager, Leland B. 1976. International monetary relations: Theory, histon, and policy. $2 \mathrm{~d}$ ed. New York: Harper and Row. 